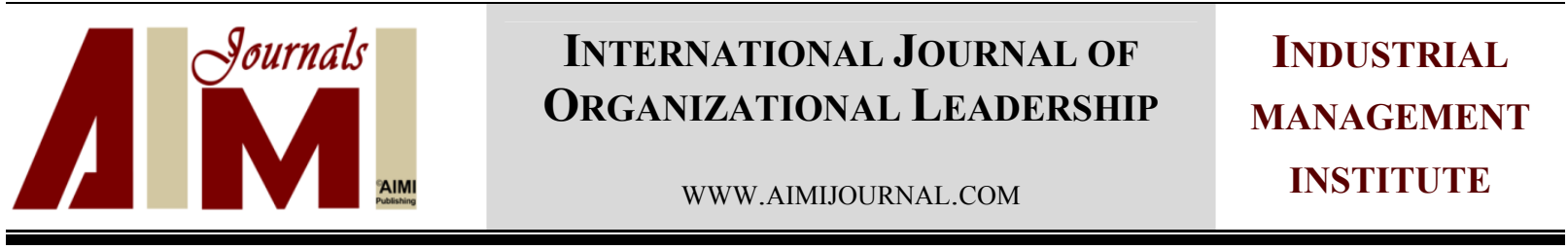

\title{
Happiness in the light of organizational spirituality: Comprehensive approach
}

\author{
Nour Mohammad Yaghoubi*, Zahra Motahhari \\ University of Sistan and Baluchestan, Zahedan, Iran
}

\begin{abstract}
Keywords:

Spirituality, Happiness,

Organization,

Organizational Spirituality

Change in lifestyle, reduction of social intimate relationships, material affiliations, decline of spirituality, and negligence of heart are among the factors distracting the inner peace. Today, the human generation looks for a way to achieve inner peace in the stressful, depressing, and distressing modern world. Spiritual freedom as one of the excellent human soul needs extends the horizon of human vision beyond the material world. Therefore, if today's humans return to spirituality, most of their sufferings will end. The present research focuses on the two variables, namely organizational spirituality and happiness to investigate the relationship between these two variables in one of the public organizations in Golestan province. Organizational spirituality questionnaire and Fordyce happiness inventory (FHI) were used for data collection. Following this, Pearson correlation test and stepwise regression were used for data analysis. The findings revealed that the organizational spirituality leads to happiness in the studied sample and organizational

Correspondence:

nm.yaghoubi@gmail.com spirituality components are significantly related to many happiness components.
\end{abstract}

CAIMI Journals

\section{Introduction}

In the late past century, a type of uniformity between inner and outer life was created in business environment. Concepts such as morality, fact, belief in God or a superior force, righteousness, conscience, magnanimity and forgiveness, search for meaning at work, and altruism suggest the advent of a new paradigm called the spiritual paradigm. Because change in lifestyle, reduction of social intimate relationships, material affiliations, decline of spirituality and negligence of heart are among the factors which distract the inner peace. Today, human generation looks for a way to achieve inner peace in the stressful, depressing, and distressing 
modern world. In present studies of organization and management, it is stated that the concept of spirituality and spirituality at work can be a solution for organizational malfunctions of staff such as alienation, stress, extreme compromise, and depersonalization (Yazdani, Kazemi Najaf Abadi, \& Salimi, 2011). Not only human can achieve peace, joy, and happiness in his personal life, but he can also achieve all that in his work life which are the results of spirituality (Ebrahimpoor, Habibian, Janalizadeh, \& Dehghani, 2011).

Moshbeki, Bashokuh, and Alipour (2006) state that spiritual needs should be met at work environment. Work can be satisfying and meaningful when it helps to satisfy people's spiritual needs. A spiritual work environment has a direct effect on staff happiness, reduction of displacement, stress, fatigue, and absence from work. In such organizations, the staff is more committed to their organizational duties (Yazdani et al., 2011).

Since human resources are considered the most valuable production factor and asset of any organization, one of the organization's main goals should be keeping the staff happy and one way to do it, is to provide them with a spiritually happy work environment. Accordingly, in the present research, by investigating the relationship between organizational spirituality and happiness of a governmental organization of Iran's Golestan province, it was tried to answer the fundamental question that what type of relationship exists between the organizational happiness and spirituality in the studied sample.

\section{The Literature Review}

\section{Happiness at Workplace}

Being happy and having a good attitude have practical and functional consequences in personal life and work performance. Happiness awakens a person's activity, increases his awareness, strengthens his creativity, facilitates his social relations, develops his political participation, and helps to maintain his health and increases his lifetime (Neshatdoost et al., 2009). In other words, happiness is a positive concept which results in a better work relationship among employees in a work environment (Bagheri, Akbari, \& Hatami, 2011). Research have shown that if humans employed in organizations and houses are happy and healthy, then their performance doubtlessly increases. Many years ago, industrial countries' researchers had found out that the adjustment of brightness, temperature, humidity, and environmental noise directly affects individuals' performance. Therefore, it can be concluded that one effective way to increase efficiency at work environment is to use happy human resources (Bahadorinezhad, 2004).

In a research, Neshatdoost et al. (2009) determined the factors influencing happiness among Mobarakeh Steel Company employees. The results showed that the employees' happiness is significantly related to their life satisfaction, optimism, family satisfaction, spouse happiness, sports, job satisfaction, partying, belief in god, art activities, studying, travelling, psychological problems, and history of physical illness. In a research, Olsson, Gärling, Ettema, Friman, and Fujii (2013) studied happiness and satisfaction in commutes to work. They stated that for many people, happiness enables them to continue their everyday life routine; in other words, if there are more positive feelings than the negative ones, people can continue their daily life. Olsson et al. studied commutes to work in three of the largest Swedish urban areas in their research. 
Their findings revealed that satisfaction from commutes to work results in overall happiness. The findings also showed that emotions are either positive or neutral in the commutes.

\section{Spirituality and Work Environment}

The concept of spiritually has different definitions in different cultures. Some believe that the human nature is spiritual. Spirituality can be considered as being related to humanity, goodness, and collective values (Dei, 2002). In another definition, it is defined as a series of organizational values evident in the culture of that organization which causes the development of employees through work process and the creation of the sense of belonging to others in a way that everyone feels perfect and happy (Giacalone \& Jurkiewicz, 2004). Mitrof and Denton (1999) defines spirituality as the will to search for the ultimate purpose of life and to live based on this very purpose.

Islamic spirituality is a religion-based spirituality. The sources for Islamic spirituality are Qoran and the sayings of Mohammad the prophet. Islamic languages have different terms for spirituality which contain various meanings including the conscience, right, universe of meaning, grace of God, concept of moral perfection, beauty, life, and remembrance of God (Farhangi \& Rastgar, 2006).

Spirituality is not the same as religiousness rather it is a structure with the following 9 dimensions, namely supernatural, meaning and purpose in life, having health in life, sanctity in life, not paying attention to material values, altruism, awareness of tragedy, idealism, and fruits of spirituality. In Elkins' (1998) view, genuine spirituality is to love all beings. Although there is a relationship between religion and spirituality, but spirituality is rather personal, whereas religion is a reflection of spirituality in personal religion texture and includes social and personal traditions and customs (Moher, 2006). The term "religion" is literally taken from the Latin root "Religio" which means "coercion" or "confinement" (Fontana, 2003). Spiritually is taken from the Latin root "Spirititas" which means "life role" or "a way of being" (West, 1999).

People are very willing to experience spirituality in personal and work affairs as well as other life areas (Moghimi, Rahbar, \& Eslami, 2007). Nowadays, organizations will be successful if they answer all the changed needs of employees including their spiritual needs (Rastgar \& Vares, 2010). A number of studies have shown that changes in individuals, societies, and organizations suggest major influential forces that create a new pattern at workplace in a way that this pattern requires uniform approaches towards life and work. By emphasizing and concentrating on these phenomena of changes, according to Oliveira (2004), societies should design a new work contract which has shorter working weeks. Doing so, people can dedicate more time to other aspects of their life and give more value to volunteer and group works (Oliveira, 2004).

In Donde and Duchon's (2000) view, employees will have meaningful work when they have their own individual goals in their life (Daniel, 2010). In this regard, the involvement of spirituality in an organization makes its employees get a uniform view towards the organization, their family, and society. Often, employees' life, family, and spiritual works are separate (Cavanagh, 1999). When employees' work life is linked to their spiritual life, it will 
create a powerful force in their lives. Having such force, people can have a more enjoyable, balanced, and meaningful work despite thousands of hours of work. The linkage between work and spiritual lives creates more satisfaction in people of their work. As a result, organizations with more creative and efficient employees will have more innovations (Gibbons, 2001). According to Malik, Naeem, and Ali (2011), the understanding of spirituality is an important part of human development at workplace. Therefore, it is a part of management education which has multiple benefits such as more compassion in the workplace, more creativity, outcome, and flexibility.

In a study that focused on the relationship between job satisfaction and job enrichment, spirituality in the workplace was considered as an interfering variable and the relationship between spirituality at workplace and job satisfaction was positively confirmed. This study stated that if employees have spiritual dimensions at workplace, they can achieve their life purpose (Amal \& Awan, 2011).

In a research, Cohen (2002) stated that there is a clear relationship between religion and happiness although certain religiousness aspects are not clearly linked to life satisfaction or are different for people with different religions. He mentioned that, in any case, religion and spirituality along with religious beliefs predict happiness and quality of life for people with different religions. Doolittle and Farrell (2004) claimed that the level of depression in people who are highly spiritual is generally lower. They stated that attendance at religious ceremonies does not really affect the level of depression, but it is a factor that separates healthy people from depressed ones and this factor included belief in a higher power, prayer to this power and relationship with it.

Experts agree upon three dimensions for spirituality at workplaces, namely meaningful work, sense of solidarity and belonging, and alignment with organizational values and goals (Donde \& Duchon, (2000); Miliman, Czaplewski, \& Ferguson, (2003)).

Individual spirituality monitors the personal experience of an individual. This means that a person feels when he is in a compassionate group, work is meaningful for him, and has an inner life including spiritual beliefs which may manifest in the form of prayer and give him hope and life. In a group, a person feels that he grows and develops and that others give value to him. Individual accountability creates constructive links to other people and also, the person's contemplation of himself and his life is linked to increased spirituality at this level. The employee happiness becomes more important for a work unit if the better conditions for the development of their talents and abilities will be provided. This drives them to learn new skills. If these characteristics are seen at an organizational level, then the spirituality can be formed at the organizational level. In other words, spirituality components at this level consist of the organization's values and the relationship between the organization and the individual (Donde \& Duchon, 2000).

\section{Method}

In the current research, all the staff of a public organization of Golestan province were selected as the statistical population which includes 250 individuals. Out of this number, a sample size 
of 152 was randomly selected based on Morgan sampling table. Two questionnaires were used to measure the organizational spirituality and happiness.

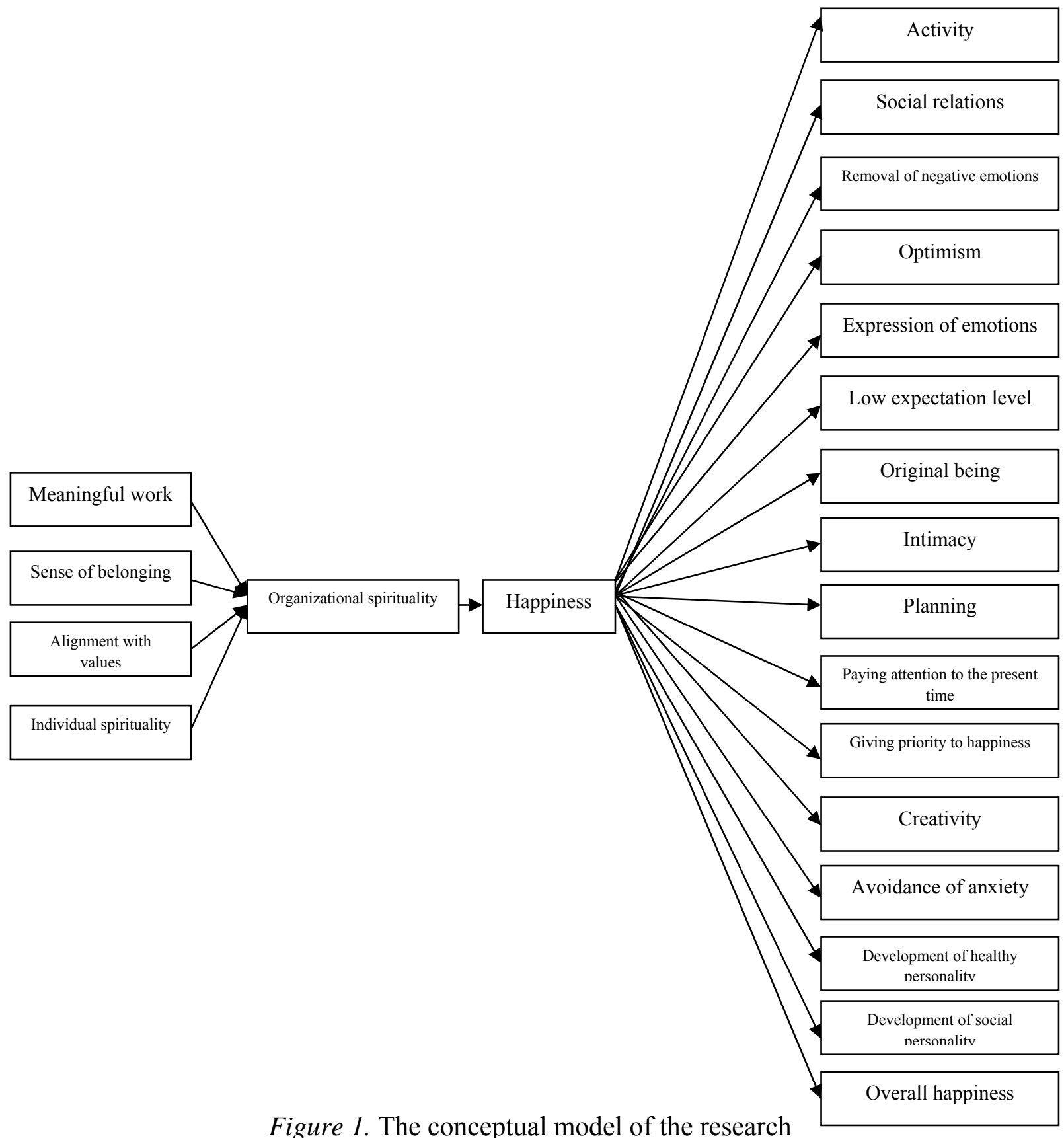

The questionnaire related to organizational spirituality was designed from the two scales of spirituality at workplace provided by Donde and Duchon (2000) and Miliman et al. (2003), and then the individual (religious) spiritual dimension was conformed according to Iranian culture and Islamic traditions. This questionnaire measures the four dimensions of meaningfulness of work, sense of solidarity to colleagues, alignment with organizational values, and individual spirituality dimension (Mohammadi, 2010). The reliability of this questionnaire is calculated in the present research with the use of Cronbach's alpha which was 0.86 . 
To measure the happiness, Fordyce standard happiness questionnaire was used. According to Badri, Liaghatdar, Abedi, \& Jafari (2006), Fordyce suggested four principles for happiness. As Ali Mohammadi and Azarbayjani (2008) mentioned, based on the 14 skills provided by Fordyce, Eysenck (1990) provided some tools to measure these skills. He considered three questions for each of the fourteen principles. He also placed three questions for measuring the overall happiness in the questionnaire.

According to Badri et al. (2006) in the study done at the University of Esfahan, they concluded that expression of emotions could be added as a skill to the collection of the 14 skills of Fordyce. At the end, these tools were translated and reviewed at the university of Esfahan, and is prepared under the title of the list of Fordyce-Esfahan happiness. The validity of this questionnaire measured for the 200-member group which was 0.92. In a group with 50 members, the validity measure was 0.70 . Figure 1 shows the conceptual model of the research.

\section{Research Hypothesis}

The following hypothesis guided the study:

There is a significant relationship between the components of organizational spirituality and happiness.

\section{Results}

In this research, Pearson correlation coefficient test and stepwise regression were used to analyze the data and the analyses were done using of SPSS16 software. Table 1 presents the descriptive data related to the examinees' topographic findings.

Table 1

Descriptive Data Related to the Examinees’ Topographic Findings

\begin{tabular}{lccc}
\hline & & Frequency & Frequency Percentage \\
\hline Education & Diploma & 27 & 17.76 \\
& Graduate & 68 & 44.73 \\
\multirow{2}{*}{ Gender } & Masters' Degree and Higher & 57 & 37.5 \\
& Male & 142 & 93.43 \\
Marital Status & Female & 10 & 6.57 \\
& Married & 145 & 95.39 \\
History of Work & Single & 7 & 4.6 \\
& Less than 10 Years & 16 & 10.52 \\
& From 10-20 Years & 74 & 48.68 \\
\hline
\end{tabular}

As is shown in Table 1, in the sample of the study, most individuals were married men with graduate degree. In addition, most individuals had a work history of 10-20 years. Table 2 exhibits the organizational spirituality dimensions' correlation coefficients. The data in Table 2 shows that the dimensions of organizational spirituality had a positive and significant relationship with each other. Except the individual spirituality component which did not have a significant relationship with meaningful work, sense of belonging to organization, and the alignment with organizational goal and it was only significantly related to overall happiness, 
other components had significant relationships with each other and with increase in each of the organizational spirituality components, it can be seen that the other ones increase as well.

Table 2

Organizational Spirituality Dimensions' Correlation Coefficients

\begin{tabular}{|c|c|c|c|c|c|}
\hline & Happiness & Meaningful Work & Belonging & Alignment with Goals & Individual Spirituality \\
\hline Happiness & 1 & & & & \\
\hline \multirow[t]{2}{*}{ Meaningful Work } & 0.394 & 1 & & & \\
\hline & 0.000 & & & & \\
\hline \multirow[t]{2}{*}{ Belonging } & 0.563 & 0.754 & 1 & & \\
\hline & 0.000 & 0.000 & & & \\
\hline \multirow[t]{2}{*}{ Alignment with Goals } & 0.502 & 0.548 & 0.770 & 1 & \\
\hline & 0.000 & 0.002 & 0.000 & & \\
\hline \multirow[t]{2}{*}{ Individual Spirituality } & 0.210 & 0.245 & 0.059 & 0.240 & 1 \\
\hline & 0.000 & 0.239 & 0.779 & 0.248 & \\
\hline
\end{tabular}

For example, with increase in the dimension of meaningful work in the organization, it is possible to result in the increase in the sense of belonging to organization, alignment with organization's goals and finally, overall happiness in the organization. Similarly, concerning other components, this result can be obtained from Table 2 .

Dimensions 1 to 16 of Table 3, respectively include activity, social relations, removal of negative emotions, optimism, expression of emotions, low expectation level, original being, intimacy, planning, attention to the present time, giving priority to happiness, creativity, avoidance of anxiety, development of healthy personality, development of social personality, and overall happiness.

As Table 3 shows, except in two dimensions, other happiness components with more than three dimensions at $95 \%$ degree of significance have significant relationships with each other. The component activity is only related to the components of social relations and overall happiness. In interpreting this component, it can be said that with increased activity, social relations increase (correlation coefficient 0.634 and significance degree of 0.001) and then, overall happiness (with a correlation coefficient of 0.803 and significance degree of 0.000 ) are created, but activity has no role in creating and increasing other components such as removal of negative emotions, expression of emotions, low expectation level, etc. Table 3 presents the happiness components' correlation coefficients.

Also, the thirteenth component that is the component of avoidance of anxiety, has a significant relationship with development of healthy personality (with a correlation coefficient of 0.514 and significance degree of 0.009), expression of emotions (with a correlation coefficient of 0.394 and significance degree of 0.051 ) and paying attention to the present time (with a correlation coefficient of 0.467 and significance degree of 0.019). This means that the avoidance of anxiety can help to develop a healthy personality.

Following this, since the correlation coefficients express mutual relations, it is possible to say that that to avoid anxiety, only the three components of happiness including development of healthy personality, expression of emotions, and paying attention to the present time should 
be considered. However, avoidance of anxiety will not increase activity, creativity, optimism, giving priority to happiness, and other happiness components.

Table 3

Happiness Components' Correlation Coefficients

\begin{tabular}{|c|c|c|c|c|c|c|c|c|c|c|c|c|c|c|c|c|}
\hline & 1 & 2 & 3 & 4 & 5 & 6 & 7 & 8 & 9 & 10 & 11 & 12 & 13 & 14 & 15 & 16 \\
\hline 1 & 1 & & & & & & & & & & & & & & & \\
\hline 2 & $\begin{array}{l}0.634 \\
0.001\end{array}$ & 1 & & & & & & & & & & & & & & \\
\hline \multirow[t]{2}{*}{3} & 0.391 & 0.658 & 1 & & & & & & & & & & & & & \\
\hline & 0.053 & 0.000 & & & & & & & & & & & & & & \\
\hline \multirow[t]{2}{*}{4} & 0.154 & 0.331 & 0.510 & 1 & & & & & & & & & & & & \\
\hline & 0.463 & 0.106 & 0.009 & & & & & & & & & & & & & \\
\hline \multirow[t]{2}{*}{5} & 0.362 & 0.762 & 0.716 & 0.555 & 1 & & & & & & & & & & & \\
\hline & 0.075 & 0.000 & 0.000 & 0.004 & & & & & & & & & & & & \\
\hline \multirow[t]{2}{*}{6} & 0.099 & 0.425 & 0.455 & 0.545 & 0.637 & 1 & & & & & & & & & & \\
\hline & 0.637 & 0.034 & 0.022 & 0.005 & 0.001 & & & & & & & & & & & \\
\hline \multirow[t]{2}{*}{7} & 0.268 & 0.369 & 0.614 & 0.487 & 0.546 & 0.608 & 1 & & & & & & & & & \\
\hline & 0.195 & 0.069 & 0.001 & 0.014 & 0.005 & 0.001 & & & & & & & & & & \\
\hline \multirow[t]{2}{*}{8} & 0.338 & 0.589 & 0.606 & 0.632 & 0.789 & 0.376 & 0.667 & 1 & & & & & & & & \\
\hline & 0.098 & 0.002 & 0.001 & 0.001 & 0.000 & 0.000 & 0.000 & & & & & & & & & \\
\hline \multirow[t]{2}{*}{9} & 0.289 & 0.723 & 0.699 & 0.510 & 0.776 & 0.781 & 0.653 & 0.723 & 1 & & & & & & & \\
\hline & 0.169 & 0.000 & 0.000 & 0.009 & 0.000 & 0.000 & 0.000 & 0.000 & & & & & & & & \\
\hline \multirow[t]{2}{*}{10} & 0.201 & 0.492 & 0.770 & 0.621 & 0.699 & 0.631 & 0.756 & 0.353 & 0.760 & 1 & & & & & & \\
\hline & 0.336 & 0.013 & 0.000 & 0.001 & 0.000 & 0.001 & 0.003 & 0.006 & 0.000 & & & & & & & \\
\hline \multirow[t]{2}{*}{11} & 0.217 & .0315 & 0.551 & 0.680 & 0.683 & 0.578 & 0.744 & 0.728 & 0.578 & 0.556 & 1 & & & & & \\
\hline & 0.297 & 0.125 & 0.000 & 0.000 & 0.000 & 0.002 & 0.000 & 0.000 & 0.002 & 0.003 & & & & & & \\
\hline \multirow[t]{2}{*}{12} & 0.234 & 0.404 & 0.467 & 0.711 & 0.706 & 0.639 & 0.493 & 0.781 & 0.572 & 0.472 & 0.809 & 1 & & & & \\
\hline & 0.259 & 0.045 & 0.018 & 0.000 & 0.000 & 0.001 & 0.012 & 0.000 & 0.003 & 0.017 & 0.000 & & & & & \\
\hline \multirow[t]{2}{*}{13} & 0.226 & 0.279 & 0.321 & 0.034 & 0.394 & 0.322 & 0.195 & 0.159 & 0.252 & 0.467 & 0.164 & 0.042 & 1 & & & \\
\hline & 0.278 & 0.177 & 0.118 & 0.870 & 0.051 & 0.117 & 0.350 & 0.449 & 0.224 & 0.019 & 0.434 & 0.841 & & & & \\
\hline \multirow[t]{2}{*}{14} & 0.363 & 0.531 & 0.678 & 0.572 & 0.741 & 0.569 & 0.460 & 0.702 & 0.561 & 0.739 & 0.660 & 0.711 & 0.514 & 1 & & \\
\hline & 0.075 & 0.006 & 0.000 & 0.003 & 0.000 & 0.003 & 0.021 & 0.001 & 0.004 & 0.000 & 0.000 & 0.000 & 0.009 & & & \\
\hline \multirow[t]{2}{*}{15} & 0.228 & 0.761 & 0.684 & 0.486 & 0.724 & 0.551 & 0.510 & 0.721 & 0.685 & 0.550 & 0.439 & 0.546 & 0.302 & 0.682 & 1 & \\
\hline & 0.273 & 0.000 & 0.000 & 0.014 & 0.000 & 0.004 & 0.009 & 0.000 & 0.000 & 0.004 & 0.012 & 0.005 & 0.142 & 0.000 & & \\
\hline \multirow[t]{2}{*}{16} & 0.803 & 0.740 & 0.584 & 0.367 & 0.613 & 0.402 & 0.345 & 0.562 & 0.520 & 0.453 & 0.391 & 0.407 & 0.401 & 0.614 & 0.453 & 1 \\
\hline & 0.000 & 0.000 & 0.002 & 0.071 & 0.001 & 0.046 & 0.091 & 0.003 & 0.008 & 0.023 & 0.054 & 0.044 & 0.047 & 0.001 & 0.023 & \\
\hline
\end{tabular}

The component of social relations has a significant relationship with the following components, namely activity, removal of negative emotions, expression of emotions, intimacy, planning, development of healthy and social personality, and overall happiness. This consideration implies that increased social relations results in the development of a healthy and social personality, removal of negative emotions, increased intimacy, and planning at work.

The component of removing negative emotions, at the significance degree of $90 \%$, has a significant relationship with the following components including social relations, optimism, expression of emotions, original being, intimacy, planning, paying attention to the present time giving priority to happiness, development of healthy and social personality, and overall happiness.

The component of optimism has a significant relationship with the 9 following happiness components, namely expression of emotions, low expectation level, intimacy, planning, paying 
attention to the present time, giving priory to happiness, creativity and development of healthy personality.

The component of expression of emotions has a significant relationship with all the happiness components except the components of activity and avoidance of anxiety. Moreover, the component of low expectations level has a significant relationship with all the happiness components except the two components of activity and avoidance of anxiety.

The component of original being has a significant relationship with the following components including removal of negative emotions, expression of emotions, optimism, paying attention to the present time, giving priority to happiness, and development of social personality. The components of intimacy and planning have a significant relationship with all the happiness components except with the components of activity and avoidance of anxiety.

The component of paying attention to the present time, has a significant relationship with all the components of happiness except for the components of activity, creativity, and avoidance of anxiety. This means that with increased attention to the present time, it is possible to remove negative emotions, increase optimism in a person, and help the person with expression of his emotions, lowering of expectations, original being, intimacy increasing, planning and giving priority to happiness. It also helps him to avoid anxiety, increase social relations and creativity and develop social and healthy personality.

The component of giving priority to happiness has a significant relationship with all the happiness components except for the five components of activity, social relations, avoidance of anxiety, development of healthy personality, and overall happiness.

The component of creativity, in addition to having a relationship with the components of social relations, removal of negative emotions, optimism, expression of emotions, low expectation level, original being, intimacy, planning, paying attention to the present time and giving priority to happiness which was previously mentioned has a significant relationship with the components of development of healthy and social personality. Regarding this component, it can be said that the creativity makes a person pay more attention to planning, look at his surrounding world more optimistically, do things that make him happy, and build a healthy and social personality for himself.

The component of developing a healthy personality has a significant relationship with all the happiness components except for the component of activity for which, the 0.075 degree of significance shows no significant relationship between these two dimensions of happiness.

The component of development of a social personality has a significant relationship with all the components except for the components of activity and avoidance of anxiety.

And finally, the component of overall happiness measurement in FHI has a significant relationship with the following components, namely activity, social relations, removal of negative emotions, expression of emotions, low expectation level, intimacy, planning, paying attention to the present time, giving priority to happiness, creativity, avoidance of anxiety, development of healthy personality and development of social personality. This highlights that by increasing any of these components, it is possible to increase happiness in a person. In other words, the component of overall happiness in FHI is significantly related to all the happiness 
components except for the two components of optimism (significance degree of 0.071) and original being (significance degree of 0.091). Table 4 shows the research findings.

Table 4

Research Findings

\begin{tabular}{|c|c|c|c|c|}
\hline Happiness & $\begin{array}{c}\text { Meaningful Work } \\
\text { Correlation Coefficient } \\
\text { Degree of Sig } \\
\end{array}$ & $\begin{array}{c}\text { Sense of Belonging } \\
\text { Correlation Coefficient } \\
\text { Degree of Sig } \\
\end{array}$ & $\begin{array}{c}\text { Alignment with } \\
\text { Organization Goals } \\
\text { Correlation Coefficient } \\
\text { Degree of Sig }\end{array}$ & $\begin{array}{c}\text { Individual Spirituality } \\
\text { Correlation Coefficient } \\
\text { Degree of Sig } \\
\end{array}$ \\
\hline \multirow[t]{2}{*}{ Activity } & 0.355 & 0.336 & 0.366 & 0.055 \\
\hline & 0.051 & 0.101 & 0.072 & 0.794 \\
\hline \multirow[t]{2}{*}{ Social Relations } & 0.240 & 0.305 & 0.412 & 0.125 \\
\hline & 0.249 & 0.138 & 0.040 & 0.552 \\
\hline \multirow{2}{*}{$\begin{array}{l}\text { Removal of Negative } \\
\text { Emotions }\end{array}$} & 0.205 & 0.423 & 0.468 & 0.388 \\
\hline & 0.327 & 0.035 & 0.018 & 0.055 \\
\hline \multirow[t]{2}{*}{ Optimism } & 0.194 & 0.373 & 0.199 & 0.138 \\
\hline & 0.353 & 0.056 & 0.339 & 0.512 \\
\hline \multirow[t]{2}{*}{ Expression of Emotions } & 0.451 & 0.586 & 0.467 & 0.238 \\
\hline & 0.024 & 0.002 & 0.019 & 0.251 \\
\hline \multirow[t]{2}{*}{ Low Expectation Level } & 0.451 & 0.431 & 0.358 & 0.174 \\
\hline & 0.024 & 0.032 & 0.079 & 0.406 \\
\hline \multirow[t]{2}{*}{ Original Being } & 0.096 & 0.223 & 0.174 & 0.321 \\
\hline & 0.649 & 0.284 & 0.407 & 0.054 \\
\hline \multirow[t]{2}{*}{ Intimacy } & 0.371 & 0.295 & 0.201 & 0.322 \\
\hline & 0.058 & 0.152 & 0.335 & 0.116 \\
\hline \multirow[t]{2}{*}{ Planning } & 0.247 & 0.421 & 0.442 & 0.198 \\
\hline & 0.233 & 0.041 & 0.027 & 0.343 \\
\hline \multirow{2}{*}{$\begin{array}{l}\text { Paying Attention to the } \\
\text { Present Time }\end{array}$} & 0.241 & 0.607 & 0.598 & 0.228 \\
\hline & 0.245 & 0.001 & 0.002 & 0.273 \\
\hline \multirow[t]{2}{*}{ Giving Priority to Happiness } & 0.194 & 0.380 & 0.173 & 0.190 \\
\hline & 0.352 & 0.051 & 0.409 & 0.363 \\
\hline \multirow[t]{2}{*}{ Creativity } & 0.418 & 0.367 & 0.196 & 0.302 \\
\hline & 0.038 & 0.072 & 0.348 & 0.142 \\
\hline \multirow[t]{2}{*}{ Avoidance of Anxiety } & 0.313 & 0.577 & 0.530 & 0.271 \\
\hline & 0.128 & 0.003 & 0.006 & 0.189 \\
\hline \multirow{2}{*}{$\begin{array}{l}\text { Development of Healthy } \\
\text { Personality }\end{array}$} & 0.433 & 0.580 & 0.520 & 0.303 \\
\hline & 0.031 & 0.002 & 0.008 & 0.141 \\
\hline \multirow{2}{*}{$\begin{array}{l}\text { Development of Social } \\
\text { Personality }\end{array}$} & 0.090 & 0.167 & 0.350 & 0.331 \\
\hline & 0.670 & 0.426 & 0.056 & 0.106 \\
\hline \multirow[t]{2}{*}{ Overall Happiness } & 0.339 & 0.463 & 0.312 & 0.107 \\
\hline & 0.097 & 0.020 & 0.129 & 0.611 \\
\hline
\end{tabular}

As the findings in Table 4 show, the research theory is confirmed. This means that the components of happiness and organizational spirituality at the significance degree of $95 \%$ are significantly related to each other for the following cases: At the significance degree of $95 \%$, meaningful word is significantly related to activity, expression of emotions, low expectation level, intimacy, creativity, and development of healthy personality.

At the significance degree of $95 \%$, sense of belonging is significantly related to the following components including the removal of negative emotions, optimism, expression of 
emotions, low expectation level, planning, paying attention to the present time, giving priority to happiness, avoidance of anxiety, development of healthy personality, and overall happiness.

At the significance degree of $95 \%$, alignment with organization values is significantly related to the following components, namely social relations, removal of negative emotions, expression of emotions, planning, paying attention to the present time, avoidance of anxiety, development of healthy personality and development of social personality.

At the significance degree of $95 \%$, individual spirituality is significantly related to the components of negative emotions and original being. Table 5 represents the results of the correlation test for the two components of organizational spirituality and happiness.

Table 5

Results of the Correlation Test for the Two Components of Organizational Spirituality and Happiness

\begin{tabular}{lcc}
\hline Pearson Correlation & Happiness & Organizational Spirituality \\
\hline Happiness & 1 & 0.555 \\
& 125 & 0.000 \\
& & 152 \\
Organizational Spirituality & 0.555 & 1 \\
& 0.000 & 152 \\
\hline
\end{tabular}

As Table 5 shows, the value of the Pearson correlation coefficient is 0.555 for the two variables of happiness and organizational spirituality. The Sig number observed is smaller than 0.05 or is actually zero which is smaller than the standard degree of significance $(\alpha=0.05)$. Therefore, it can be said that at the significance degree of $95 \%$, there is a significant relationship between these two variables. Table 6 shows the happiness stepwise regression from organizational spirituality dimensions.

Table 6

Happiness Stepwise Regression from Organizational Spirituality Dimensions

\begin{tabular}{cccccc}
\hline Variable & $\mathrm{R}$ & $\mathrm{R}^{2}$ & Beta & $\mathrm{T}$ & $\mathrm{Sig}$ \\
\hline Sense of Belonging & 0.563 & 0.317 & 0.563 & 3.270 & 0.003 \\
\hline
\end{tabular}

In the present research, stepwise regression was used to investigate the prediction of happiness based on organizational spirituality dimensions. The results in Table 6 show that only the sense of belonging was entered into the regression equation which resulted in a value of $31.7 \%$ for happiness. The rest of the organizational spirituality dimensions (meaningful work alignment with organizational goals and individual spirituality) were not qualified to enter the regression equation, so they were removed. Sense of belonging has a significant relationship with (significance degree $=0.003$ and $\beta=0.563$ ) happiness and this is a unique and positive predictor for this variable. Hence, the component of the sense of belonging had the greatest share in the prediction and determination of happiness. 


\section{Conclusion}

The aim of the current research was to investigate the significance of the relationship between the components of organizational spirituality and happiness. In the section for data analysis, the significance of these relationships was studied. Few research have been done to offer happiness approaches at workplace which use organizational spirituality. A research which is somehow related to this topic is the study by Motahari, Aalee, and Ahmadi Seyed Abedi (2013). Their findings indicated that organizational spirituality with all of its dimensions can create a sense of happiness among the people of an organization. Baradaran and Ranjbar Noshari (2009), Kazemi, Alayi, and Ramazani (2008), Mansouri, Edalatzadeh, and Bakhshipour Roodsari (2009), and Mousavi and Peyvastegar (2009) showed that many positive characteristics which are caused by mental health are related to happiness and have a positive correlation with it. In the present research, beside these variables, meaningful work, sense of belonging and correlation, and alignment with organizational values and religiousness are significantly related to happiness. In addition, the results of research done by Manzari Tavakoli and Araghipour (2010) and Heydari Rafaat, Tahmasebi, and Ghasemi Kheshab (2009) showed that there is a positive relationship between happiness and religiousness. Moreover, the research of Ghobari Benab, Motevallipour, and Habib Asgarabad (2009) showed a negative relationship between anxiety and depression and spirituality in the students of Tehran University. Doolittle and Farrell (2004) stated in a research that people with high spirituality levels, have lower depression levels. These researchers stated that attendance at religious ceremonies does not have much effect on people's depression levels and the things that distinguish healthy people from depressed ones are belief in a higher power, prayer to this power, and relationship with it.

According to the research findings, some suggestions in alignment with the present research about organizational spirituality components are given. Considering the dimension of meaningful work, creating entertainment programs for staff, providing conditions under which the staff can have a friendly relation with their colleagues, paying attention to people's family lives, and creation of counseling centers for family are of great importance. It is also possible to make work exciting for the staff with the use of job enrichment and career development programs.

Regarding the dimension of the sense of belonging to an organization, it is important to adjust employees' work schedule and program in a way that leaves them some time during a week to do their personal things. A person's current job and position should be made exciting and interesting and by holding entertainment programs for the staff of the studied organization, they should be made feel happier in their lives.

In the dimension of the alignment with organization goals, providing conditions at workplace under which staff would be able to express their emotions about their work, colleagues, and even the supervision method in the organization should be taken into account. Expressing the organization's goals for the people of it should be considered. Following this it should be noted that all the services and facilities the organization has provided to the people of the organization is to help them to improve their life, and that the organization does care about them. Finally, considering the dimension of individual spirituality, holding spiritual ceremonies and developing employees' spiritual dimension must also be taken into account. 


\section{References}

Ali Mohammadi, K., \& Azerbaijani, M. (2008). The relationship between the Islamic happiness and psychological happiness among the students of Qom University. Psychology \& Religion, 2(3), 7-28.

Amal, A., \& Awan, M. A. (2011). Moderating affect of workplace spirituality on the relationship of job overload and job satisfaction. Journal of Business Ethics, 104, 93-99.

Badri, E., Liaghatdar, M. J., Abedi, M. R., \& Jafari, S. E. (2006). Investigating the entrepreneurship capabilities of the students of Isfahan University. Journal of Research \& Planning in Higher Education, 12(2), 73-90.

Bagheri, F., Akbari, F., Hatami, H. R. (2011). The relationship between happiness and spiritual intelligence and demographic variables among the nurses of Fatemeh Alzahra and Bentolhoda hospitals of the city of Bushehr. Southern Medical Journal, 14(4), 256-263.

Bahadorinezhad, M. (2004). Management by emphasis on Spirituality. Tadbir, 147, 33-40.

Baradaran, M., \& Ranjbar Noshary, F. (2009). The relationship between happiness, self-esteem, and social histories in students. A paper presented at the First National Conference on Happiness, University of Sistan and Baluchestan, Zahedan, Iran.

Cavanagh, G. (1999). Spirituality of managers: Context and critique. Journal of Organizational Change Management, 12(3), 186-199.

Cohen, A. B. (2002). The importance of spirituality in well-being for Jews and Christians. Journal of Happiness Studies, $3,287-310$.

Crosbie, R. (2008). Who defines ethics in your organizations? Industrial \& Commercial Training, 40(4), 181-187.

Daniel, J. L. (2010). The effect of workplace spirituality on team effectiveness. Journal of Management Development, 29(5), $442-456$.

Dei, G. J. S. (2002). Learning culture, spirituality and local knowledge: Implications for African schooling. International Review of Education, 48(5), 335-360.

Donde, P. A., \& Duchon, D. (2000). Spirituality at work: A conceptualization and measure. Journal of Management Inquiry, 9(2), 134-145.

Dooltile, B. R., \& Farrell, M. (2004). The association between spirituality and depression in an urban clinic. Journal of Clinical Psychiatry, 6(3), 114-118.

Ebrahimpour, H., Habibian, S., Janalizadeh, M., \& Dehghani, A. (2011). Spirituality at work: An approach for success in economic challenges. Paper presented at the National Conference on Entrepreneurship, Cooperation, Economical Jihad, Islamic Azad University, Naeen Branch, Isfahan, Iran.

Elkins, D. N. (1998). Beyond religion: A personal program for building a spiritual life outside the walls of traditional religion. Wheaton, IL: Quest Books.

Eysenck, H. J. (1990). Biological dimensions of personality. In L. A. Pervin (Ed.), Handbook of personality: Theory and research (pp. 244-276). New York: Guilford.

Farhangi, A. A., \& Rastgar, A. A. (2006). Presenting and explaining a motivational model based on employees' spirituality. Journal of Behavior, 13(20), 12-21.

Fontana, D. (2003). Psychology, religion and spirituality. Oxford, U.K.: Blackwell Publishing.

Ghobari Benab, B., Motevallipour, A., \& Habibi Asgarabad, M. (2009). The relationship of anxiety and depression with the level of spirituality among the Tehran University students. Journal of Applied Psychology, 3(10), 110-123.

Giacalone, R. A., \& Jurkiewicz, C. L. (2004). Right from wrong: The influence of spirituality on perceptions of unethical business activities. Journal of Business Ethics, 46(1), 85-97.

Gibbons, P. (2001). Spirituality at work: A pre-theoretical overview (Unpublished master's thesis). Brinbeck College, University of London.

Heydari Rafaat, A., Tahmasebi, A., \& Ghasemi Kheshab, A. (2009). The relationship between religious attitude and happiness among the students of Tehran University. A Paper presented at the First National Conference on Happiness, University of Sistan and Baluchestan, Zahedan, Iran.

Kazemi, Y., Alayi, H., \& Ramazani, G. (2008). Investigating the relationship between modesty and happiness. Paper presented at the First National Conference on Happiness. Sistan and Baluchestan Univesrity, Zahedan, Iran. 
Malik, M. E., Naeem, B., \& Ali, B. B. (2011). How do workplace spirituality and organizational citizenship behavior influence sales performance of FMCG sales force? Interdisciplinary Journal of Contemporary Research in Business, 3(8), 610-620.

Mansouri, A., Edalatzadeh, N., \& Bakhshipour Roodsari, A. (2009). Investigating the relationship between happiness and positive and negative perfectionism and mental health. A paper presented at the First National Conference on Happiness, Sistan and Baluchestan University, Zahedan, Iran.

Manzari Tavakoli, A., \& Araghipour, N. (2010). Relationship between religiosity and happiness among female students of Islamic Azad University of Kerman. Journal of Educational Psychology, 6(19), $19-45$.

Milliman, J., Czaplewski, A. J., \& Ferguson, J. (2003). Workplace spirituality and employee work attitudes: An exploratory empirical assessment. Journal of Organizational Change Management, 16(4), 426-447.

Mitrof, I. I., \& Denton, E. A. (1999). A spiritual audit of corporate America: A hard look at spirituality, religion and values in workplace. San Francisco: Jossey-Bass.

Moghimi, M., Rahbar, A. H., \& Eslami, H. (2007). Organizational spirituality and its impact on employee creativity (comparative approach). Journal of Ethics in Science \& Technology, 2(3/4), 89-98.

Mohammadi, M. (2010). Investigating the relationship between organizational spirituality and organizational citizen behavior: A case study of Zahedan municipality (Unpublished master's thesis). Sistan and Baluchestan University, Sistan and Baluchestan, Zahedan, Iran.

Moher, W. K. (2006). Spiritual issues in psychiatric care. Journal of Perspective in Psychiatric Care, 42(3), $174-183$.

Moshbeki, A., Bashokuh, M., \& Alipour, V. (2006). Spirituality and leadership. Industrial Management Studies, 14, 177-200.

Motahari, Z., Aalee, H., \& Ahmadi Seyed Abadi, S. (2013). Organizational spirituality, a solution for the people of an organization. A paper presented at the Second National Conference on Modern Management sciences, Gorgan, Iran.

Mousavi, A., \& Peyvastegar, M. (2009). The effect of self-regulation skills on adolescent girls. A paper presented at the First National Conference on Happiness, Sistan and Baluchestan University, Zahedan, Iran.

Neshatdust, H. T., Kalantari, M., Mehrabi, H. A., Palahang, H., Nouri, N. A., \& Soltani, I. (2009). Determining the factors affecting the happiness of Mobarakeh Steel Company employees. Journal of Applied Sociology, 20(1), 105-118.

Oliveira, A. (2004). The place of spirituality in organizational theory. Journal of Business Ethics and Organization Studies (EJBO), 9(2), 17-21.

Olsson, L. E., Gärling, T., Ettema, D., Friman, M., \& Fujii, S. (2013). Happiness and satisfaction with work commute. Social Indicators Research, 111(1), 255-263.

Rastgar, A. A., \& Vares, S. H. (2010). God in organization: Fusion and integration of spiritual life and working life. Journal of Management Science, 3(11), 73-99.

West, W. S. (1999). Psychotherapy and spirituality crossing the line between therapy and Religion. London: Hodder and Stroughton.

West, W. (2004). Psychotherapy and spirituality (S. Shahidi \& S. Shirafkan, Trans.) Tehran: Roshd.

Yazdani, H., Kazemi Najaf Abadi, M. R., \& Salimi, G. (2011). Investigating the intermediate role of spirituality in the relationship between the dimensions of organizational justice and spirituality implications. Journal of Business Management Perspective, 3(36), 117-133. 